\title{
Potensi Chlorella sp. dan Pseudomonas sp. dari Areal Tambang Emas sebagai Mikroorganisme Potensial Pereduksi Merkuri
}

\author{
Liswara Neneng ${ }^{1}$, Ardianoor ${ }^{2}$, Hepryandi Luwyk Djanas Usup ${ }^{3}$, Chaidir Adam¹ ${ }^{1}$ Zakaria ${ }^{1}$, \\ Arintiana Ghazella ${ }^{1}$, Srininta Br Perangin-angin ${ }^{1}$, dan Vivin Alvianita ${ }^{1}$
}

${ }^{1}$ Program Studi Pendidikan Biologi, Fakultas Keguruan dan Ilmu Pendidikan, Universitas Palangka Raya; liswaraneneng@fkip.upr.ac.id

${ }^{2}$ Jurusan Perikanan, Fakultas Pertanian, Universitas Palangka Raya

${ }^{3}$ Jurusan Teknik Sipil, Fakultas Teknik, Universitas Palangka Raya

\begin{abstract}
ABSTRAK
Kawasan hutan maupun sungai-sungai di Kalimantan Tengah, telah terdampak akibat kegiatan penambangan emas skala kecil (ilegal) selama puluhan tahun. Para penambang menggunakan merkuri sebagai bahan kimia utama dalam prosesekstraksi emas, dan setiap tahun melepaskan tidak kurang dari 1.000 ton bahan berbahaya ini ke lingkungan, baik udara maupun air. Pencemaran merkuri di lingkungan perairan, dapat dikurangi atau dihilangkan dengan menggunakan sekelompok mikroorganisme yang mampu untuk mereduksi merkuri yang disebut dengan bioremediasi. Metode bioremediasi lebih ekonomis, karena mikroorganisme memiliki kemampuan untuk mendegradasi kontaminan ke dalam bentuk yang tidak berbahaya. Bakteri dan alga yang hidup di perairan sekitar tambang emas diduga memiliki kemampuan resistensi terhadap kontaminan logam berat merkuri. Sampel bakteri dan alga yang diambil dari sekitar tambang diseleksi dengan perlakuan merkuri (Hg) untuk mengetahui potensinya sebagai bioremediator logam berat. Penelitian ini bertujuan untuk Eksplorasi dan Optimasi Mikroorganisme Potensial untuk Bioremediasi Merkuri dari Areal Tambang Emas di Sungai Kahayan. Pengambilan sampel dilakukan di 5 titik yang teridiri 3 titik di areal tambang (T1, T2, T3), 1 titik di hulu tambang (HU), dan 1 titik di hilir tambang (HI). Hasil penelitian menunjukkan: (1) mikroalga potensial bioremediasi merkuri dari areal tambang emas sungai Kahayan termasuk ke dalam genus Chlorella dan mampu bertahan dengan perlakuan konsentrasi Hg sampai 7 ppm; dan (2) bakteri potensial bioremediasi merkuri dari areal tambang emas sungai Kahayan mampu bertahan dengan perlakuan konsentrasi Hg sampai 13 ppm yang terdiri dari 3 isolat, yakni I1 (bakteri dari sampel air), I2 (bakteri dari sampel air), dan I3 (bakteri dari sampel sedimen). Ketiga isolat bakteri potensial termasuk ke dalam kelompok bakteri Gram Negatif. Isolat 1 dan isolat 3 merupakan spesies Pseudomonas sp. berdasarkan kemampuannya menghasilkan pigmen berwarna kuning pada media cair.
\end{abstract}

Kata kunci: Bioremediasi, Logam Berat, Merkuri, Mikroorganisme, Bakteri, Mikroalga, Chlorella, Pseudomonas

\begin{abstract}
Forest areas and rivers in Central Kalimantan have been affected by small-scale (illegal) gold mining activities for decades. Miners use mercury as the main chemical in the gold extraction process, and annually release no less than 1,000 tons of this hazardous material into the environment, both air and water. Mercury pollution in aquatic environments can be reduced or eliminated by using a group of microorganisms capable of reducing mercury known as bioremediation. The bioremediation method is more economical, because microorganisms have the ability to degrade contaminants into harmless forms. Bacteria and algae that live in the waters around the gold mine are thought to have the ability to resist mercury heavy metal contaminants. Bacteria and algae samples taken from around the mine were selected with mercury (Hg) treatment to determine their potential as a heavy metal bioremediator. This research aims to explore and optimize potential microorganisms for bioremediation of mercury from the gold mine area in the Kahayan River. Sampling was carried out at 5 points consisting of 3 points in the mine area (T1, T2, T3), 1 point upstream of the mine (HU), and 1 point downstream of the mine (HI). The results showed: (1) the potential microalgae bioremediation of mercury from the gold mining area of the Kahayan River was included in the Chlorella genus and was able to survive the treatment of Hg concentrations up to 7 ppm; and (2) potential mercury bioremediation bacteria from the gold mining area of the Kahayan River were able to survive with a treatment of up to $13 \mathrm{ppm} \mathrm{Hg}$ concentrations consisting of 3 isolates, namely I1 (bacteria from water samples), I2 (bacteria from water samples), and I3 (bacteria from sediment samples). The three potential bacterial isolates belong to the Gram negative bacteria group. Isolate 1 and isolate 3 are Pseudomonas sp. species based on their ability to produce yellow pigment in liquid media.
\end{abstract}

Keywords: Bioremediation, Heavy Metals, Mercury, Microorganisms, Bacteria, Microalgae, Chlorella, Pseudomonas

Citation: Neneng, L., Ardianoor, Usup, H.L.D., Adam, C., Zakaria, Ghazella, A., Perangin-angin, S., dan Alvianita, V. (2020). Potensi Chlorella sp. dan Pseudomonas sp. dari Areal Tambang Emas sebagai Mikroorganisme Potensial Pereduksi Merkuri. Jurnal Ilmu Lingkungan, 18(3), 617625, doi:10.14710/jil.18.3.617-625 
Neneng, L., Ardianoor, Usup, H.L.D., Adam, C., Zakaria, Ghazella, A., Perangin-angin, S., dan Alvianita, V. (2020). Potensi Chlorella sp. dan Pseudomonas sp. dari Areal Tambang Emas sebagai Mikroorganisme Potensial Pereduksi Merkuri. Jurnal Ilmu Lingkungan, 18(3), 617-625, doi:10.14710/jil.18.3.617-625

\section{Pendahuluan}

Kawasan hutan maupun sungai-sungai di Kalimantan Tengah, telah terdampak akibat kegiatan penambangan emas skala kecil (ilegal) selama puluhan tahun. Jumlah unit penambangan emas ini mencapai ribuan, baik yang berlokasi di daratan maupun perairan. Data jumlah unit penambang emas pada Sungai Kahayan di Kalimantan Tengah pada tahun 2014, mencapai 1563 unit dengan jumlah penambang mencapai 43.000 orang (VoA, 2013). Lokasi penambangan emas tidak menetap dan selalu berpindah-pindah.

Para penambang menggunakan merkuri sebagai bahan kimia utama dalam proses ekstraksi emas, dan setiap tahun melepaskan tidak kurang dari 1.000 ton bahan berbahaya ini ke lingkungan, baik udara maupun air. Hasil penelitian memperlihatkan bahwa konsentrasi merkuri di sungai Kahayan, berjumlah dua kali lebih banyak dari batas standar yang diijinkan oleh pemerintah (Walsh, 2013). Kandungan merkuri pada air di Sungai Kapuas Tengah telah melewati kadar baku mutu air (0,001 mg/L), dan kadar merkuri di sedimen lebih tinggi dibandingkan dengan di air (Yulianti et al., 2007).

Hingga saat ini, pencemaran merkuri akibat penambangan emas skala kecil, belum mendapatkan penanganan maksimal. Hal ini sangat membahayakan bagi kesehatan dan kehidupan para penambang, masyarakat sekitar, maupun generasi yang akan datang, karena pencemaran merkuri bersifat akumulatif pada organ tubuh makhluk hidup. Mengacu pada Minamata Convention on Mercury tahun 2015, setiap negara/wilayah, maupun para pelaku usaha wajib melakukan tindakan untuk mengurangi pencemaran merkuri di lingkungan. Para penambang emas skala kecil juga membutuhkan sentuhan teknologi untuk meminimalkan paparan merkuri yang sangat berbahaya bagi diri mereka, masyarakat umum, maupun bagi lingkungan. Teknologi yang digunakan tersebut diharapkan efektif, efisien, ekonomis, dan juga ramah lingkungan. Teknologi untuk mengurangi dan menghilangkan kontaminasi logam berat dari lingkungan merupakan salah satu kebutuhan mendesak saat ini.

Pencemaran merkuri di lingkungan perairan, dapat dikurangi atau dihilangkan dengan menggunakan sekelompok mikroorganisme yang mampu untuk mereduksi merkuri. Metode ini dikenal dengan istilah bioremediasi. Metode bioremediasi lebih ekonomis, karena mikroorganisme memiliki kemampuan untuk mendegradasi kontaminan ke dalam bentuk yang kurang/tidak berbahaya. Hasil penelitian membuktikan bahwa bioremediasi menggunakan mikroorganisme adalah yang paling efektif (Bernhard-Reversat \& Schwartz, 1997; Leung, 2004). Hal ini didukung oleh pendapat Cursino et al., 1999 yang menyatakan mikroorganisme dalam lingkungan yang terkontaminasi secara alami oleh bakteri resisten merkuri merupakan alternatif yang lebih murah dan aman dibandingkan dengan metode konvensional. Menurut Leung, 2004, bioremediasi lebih efektif, murah dan aman bagi ekosistem 618 dibandingkan dengan metore remediasi menggunakan cara fisik dan kimiawi.

Bioremediasi merkuri menggunakan bakteri sangat potensial, karena bakteri berperan utama dalam siklus global merkuri di lingkungan alami (Nascimento \& Souza, 2003). Bakteri menggunakan mekanisme intrasel untuk proses detoksifikasi merkuri, dengan cara mereduksi $\mathrm{Hg}^{2+}$ menjadi $\mathrm{Hg}^{0}$ yang tidak toksik, oleh sekelompok enzim merkuri reductase yang tergabung dalam operon mer. $\mathrm{Hg}^{0}$ yang terbentuk kemudian berdifusi keluar dari dalam sel (Wagner-Döbler et al., 2000). Bioremediasi banyak menggunakan bakteri indigenus, meskipun ada juga yang menggunakan strain bakteri atau fungi dari luar (Mellor, Paul, Christine O', \& Dave, 1996). Hal ini dilakukan karena bakteri indigenus memiliki daya adaptasi yang lebih tinggi pada lingkungannya.

Genus mikroorganisme yang telah dilaporkan hingga saat ini, kebanyakan resisten merkuri hingga $\leq$ 10 ppm (Baldi et al., 1983; Robinson \& Tuovinen, 1984; Osborn et al., 1997). Biofilm Pseudomonas putida Spi3 yang diisolasi dari sedimen sungai Spittelwasser, Jerman, mampu mereduksi merkuri pada konsentrasi 7-9 ppm (Von Canstein et al., 1999). Sebanyak 7 strain Pseudomonas sp. yang digunakan untuk mereduksi merkuri limbah pabrik kloralkali pada skala industri di Jerman, mampu mereduksi merkuri pada konsentrasi maksimal 10 ppm (Wagner-Döbler et al., 2000).

Mekanisme resisten terhadap merkuri didasarkan pada adanya sekelompok gene operon resisten merkuri yang memungkinkan bakteri untuk mereduksi ion logam merkuri yang toksik $\mathrm{Hg}^{2+} \mathrm{ke}$ dalam bentuk merkuri yang volatil $\mathrm{Hg}^{0}$ melalui mekanisme reduksi enzimatis (Summers, 1986; Misra, 1992; Barkay et al., 2003); Operon-operon ini mengandung gen yang menyandikan protein-protein fungsioal untuk regulasi (merR), transport (merT, merP) dan reduksi (merA). Terdapat juga beberapa gen tambahan berupa (merC, merF and merB) (Endo et al., 1995; Nies, 1992). MerB berperan untuk mereduksi merkuri organik. Beberapa bakteri resisten merkuri juga mampu untuk mendetoksifikasi logam berat yang lain, seperti cadmium dan timbal.

Bioremediasi menggunakan algae juga memiliki keunggulan. Salah satu keunggulannya adalah dalam prosesnya alga hanya membutuhkan cahaya dan tidak membutuhkan oksigen (Dwivedi, 2012). Karena itu bioremediasi menggunakan alga dapat sekaligus mengurangi karbondioksida dari lingkungan. Mikroalga berpotensi mengurangi atau menghilangkan senyawa toksik seperti logam berat dengan cara akumulasi, adsorpsi, atau memetabolisme menjadi substansi yang tidak berbahaya (Priyadarshani et al., 2012). Sel alga yang mati juga dapat digunakan untuk mengurangi kontaminan logam. fungsi utama terutama bertanggung jawab untuk biosorpsi ion logam berat. Beberapa contoh alga potensial untuk bioremediasi logam berat antara lain: biosorpsi logam $\mathrm{Pb}, \mathrm{Cd}, \mathrm{Hg}$ oleh Microcystis aeruginosa (Chen et al., 2005), biosorpsi $\mathrm{Cd}, \mathrm{Cr}, \mathrm{Cu}$ oleh Spirulina (Chojnacka et al., 
2005); bioakumulasi $\mathrm{Pb}$ dan Cd oleh Chladophora (Lamaia et al., 2005); biosorpsi $\mathrm{Cu}$ oleh Chlorella vulgaris (Al-Rub et al., 2006); bioremediation $\mathrm{Hg}, \mathrm{Cd}$, Pb oleh Dunaliella (Imani et al., 2011).

Bakteri dan alga yang hidup di perairan sekitar tambang emas diduga memiliki kemampuan resistensi terhadap kontaminan logam berat merkuri. Sampel bakteri dan alga yang diambil dari sekitar tambang diseleksi dengan perlakuan merkuri (Hg) untuk mengetahui potensinya sebagai bioremediator logam berat. Perlu dilakukan penelitian lebih lanjut terkait jenis bakteri dan alga apa saja yang potensial sebagai bioremediator. Penelitian ini bertujuan untuk Eksplorasi dan Optimasi Mikroorganisme Potensial untuk Bioremediasi Merkuri dari Areal Tambang Emas di Sungai Kahayan.

\section{Bahan dan Metode}

Penelitian ini termasuk jenis eksperimen di laboratorium. Kegiatan penelitian eksperimental, meliputi:

1) Optimasi kultur mikroalga untuk bioremediasi merkuri pada media cair

2) Optimasi kultur bakteri untuk bioremediasi merkuri pada media cair.

Pengambilan sampel bakteri dan mikroalga dilakukan pada bulan Agustus 2020 di Sungai Kahayan, Desa Pahawan, Kabupaten Pulang Pisau. Titik pengambilan sampel berjumlah 5 (lima) titik (Gambar 1 dan Gambar 2). Lokasi pengambilan sampel pada penelitian ini dibagi menjadi lima titik, yakni di bagian hulu, hilir, unit tambang 1, unit tambang 2, dan unit tambang 3. Areal penambangan emas pada penelitian ini berada di Desa Pahawan, Kabupaten Pulang Pisau, di Sungai Kahayan, Kalimantan Tengah. Lokasi pengambilan sampel, di bagian hulu dan hilir diberi jarak \pm 500 meter dari area tambang. Pengambilan sampel bakteri dilakukan di setiap titik sampling dengan mengambil sampel air dan sampel sedimen.

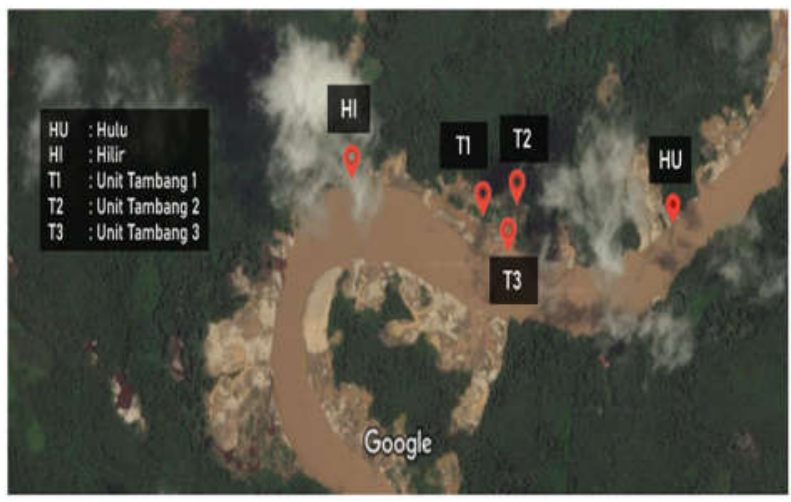

Gambar 1. Peta Lokasi Pengambilan Sampel

Seleksi dan optimasi kultur mikroalga untuk bioremediasi merkuri dilakukan 2 (dua) tahap, yakni: (1) tahap 1 dengan perlakuan $\mathrm{Hg} \mathrm{0,5} \mathrm{ppm,} 1 \mathrm{ppm}$ dan 3 ppm; dan (2) tahap 2 dengan perlakuan $\mathrm{Hg} 5$ ppm, 7 ppm, dan 9 ppm. Semua unit perlakuan dikultivasi menggunakan fotobioreaktor.
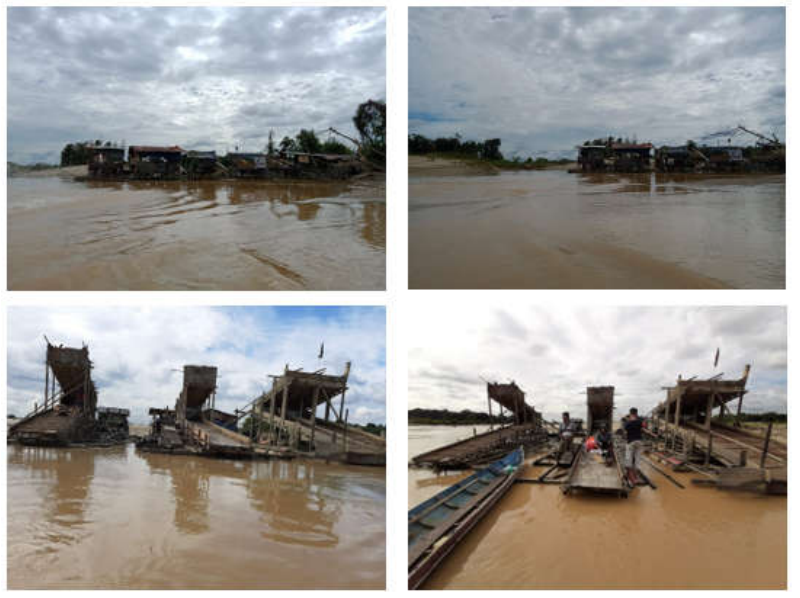

Gambar 2. Unit Tambang Emas di Lokasi Pengambilan Sampel

Seleksi dan optimasi kultur bakteri untuk bioremediasi merkuri dilakukan 4 (tiga) tahap, yakni: (1) tahap 1 dengan perlakuan $\mathrm{Hg} 1 \mathrm{ppm}, 3 \mathrm{ppm}$, dan 5 ppm; (2) tahap 2 dengan perlakuan $\mathrm{Hg} 3$ ppm, 5 ppm, 7 ppm, dan 9 ppm; (3) tahap 3 dengan perlakuan Hg 5 ppm, 7 ppm, 9 ppm, dan 11 ppm; dan (4) Tahap 4 dengan perlakuan Hg 11 ppm, 13 ppm, 15 ppm, dan 17 ppm.

Karakterisasi mikroorganisme potensial hasil seleksi dan optimasi sebagai berikut:

1) Identifikasi mikroskopis sel mikroalga potensial bioremediasi merkuri

2) Identifikasi bakteri potensial bioremediasi merkuri dengan pewarnaan Gram.

\section{Hasil dan Pembahasan}

\subsection{Seleksi dan Isolasi Mikroalga}

Perlakuan tahap 1, kultur mikroalga diberi perlakuan 3 konsentrasi $\mathrm{Hg}$, yakni 0,5 ppm, 1 ppm, dan 3 ppm dengan satu kontrol tanpa perlakuan Hg. Mikroalga menunjukkan resistensi terhadap Hg pada semua perlakuan (0,5 ppm, 1 ppm, dan 3 ppm). Hasil Tahap 1 dapat dilihat pada Gambar 3.

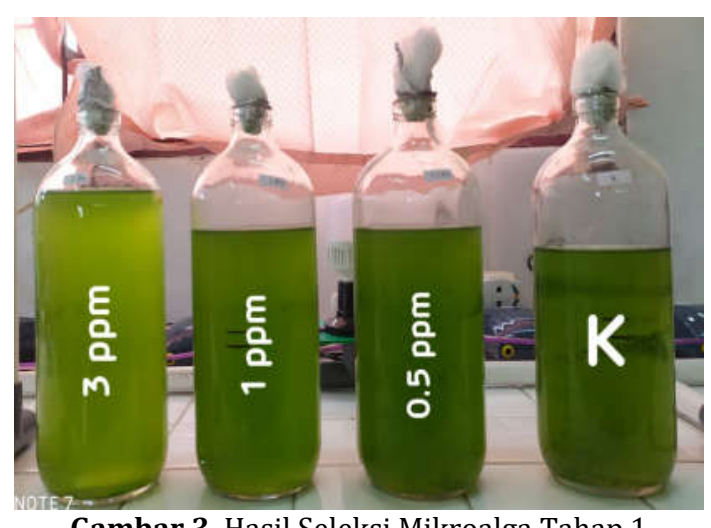

Gambar 3. Hasil Seleksi Mikroalga Tahap 1

Gambar 3 menunjukkan semua sampel mikroalga tumbuh subur pada semua perlakuan. Seleksi dilanjutkan ke tahap 2 dengan perlakuan konsentrasi Hg yang lebih tinggi, yakni 5 ppm, 7 ppm, dan 9 ppm. Hasil seleksi tahap 2 menunjukkan bahwa sampel mikroalga dapat bertahan dan tumbuh subur di media kultur dengan perlakuan Hg sampai 5 ppm (Gambar 
5). Mikroalga pada perlakuan Hg 5 ppm terlihat mulai tumbuh di hari ke-10 setelah tanam lebih lambat dibandingkan dengan kontrol yang sudah mulai terlihat tumbuh di hari ke-2 (Gambar 4). Hal ini menunjukkan mikroalga yang hidup di lingkungan yang tercemar butuh waktu lebih lama pada fase lag pertumbuhannya untuk beradaptasi. Fase lag merupakan fase di mana mikroorganisme mengalami perlambatan pada pertumbuhannya karena beradaptasi dengan lingkungan yang baru, dan lama durasi fase lag dipengaruhi oleh banyak faktor (Rolfe et al., 2012; Li, Qiu, Shi, \& Yin, 2016; Bertrand, 2019), dalam penelitian ini media kultur dengan perlakuan Hg merupakan faktor yang membuat fase lag pertumbuhan mikroalga lebih lama.

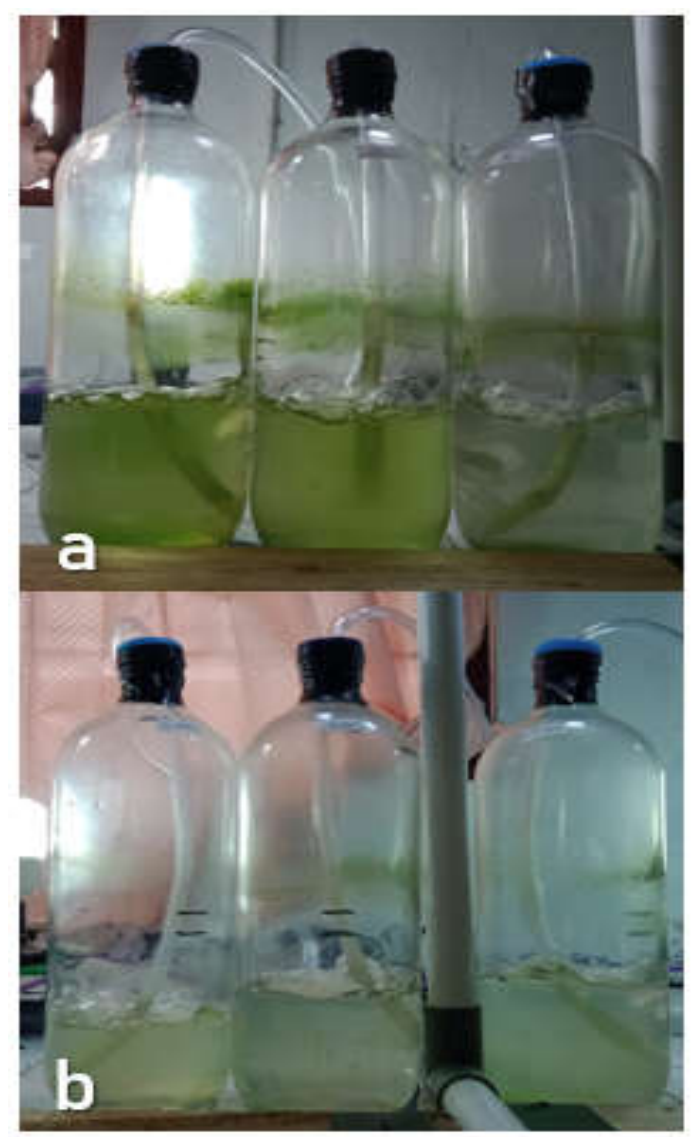

Gambar 4. Pertumbuhan Mikroalga di Hari Ke-10: (a) Kontrol; dan (b) Perlakuan Hg 5 ppm

Sel normal memiliki batas maksimal toleransi konsentrasi $\mathrm{Hg}$, seperti konsentrasi normal $\mathrm{Hg}$ pada darah kurang dari 0,01 ppm (Brune, Nordberg, Vesterberg, Gerhardsson, \& Wester, 1991; Melanson, 2017). Perlakuan Hg 7 ppm masih mengindikasikan adanya mikroalga yang tumbuh (Gambar 6). Mikroalga pada penelitian ini mampu bertahan di media kultur dengan perlakuan $\mathrm{Hg}$ sampai konsentrasi $7 \mathrm{ppm}$ dan tumbuh dengan subur di konsentrasi 5 ppm. Hal ini menunjukkan bahwa sampel mikroalga pada penelitian ini memiliki potensi sebagai bioremediator logam berat, khususnya $\mathrm{Hg}$. Penelitian Mangindara (2018) menunjukkan bahwa spesies mikroalga Chlorella sp. dapat bertahan pada media kultur sampai konsentrasi 6 ppm meskipun terjadi penghambatan dalam pertumbuhannya. Efisiensi optimal mikroalga dalam bioremediasi $\mathrm{Hg}$ sebesar 79,5\% dengan waktu kontak 96 jam dan konsentrasi stock kultur $5000 \mathrm{sel} / \mathrm{ml}$ (Soedarti, Tini, Sucipto, \& Eko, 2017).

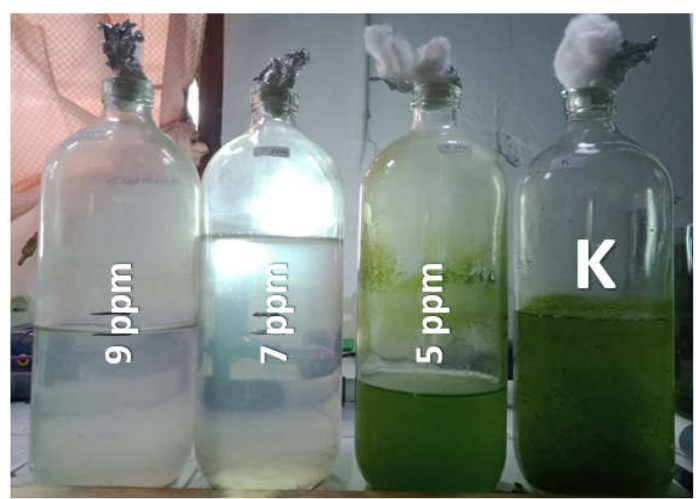

Gambar 5. Hasil Seleksi Mikroalga Tahap 2

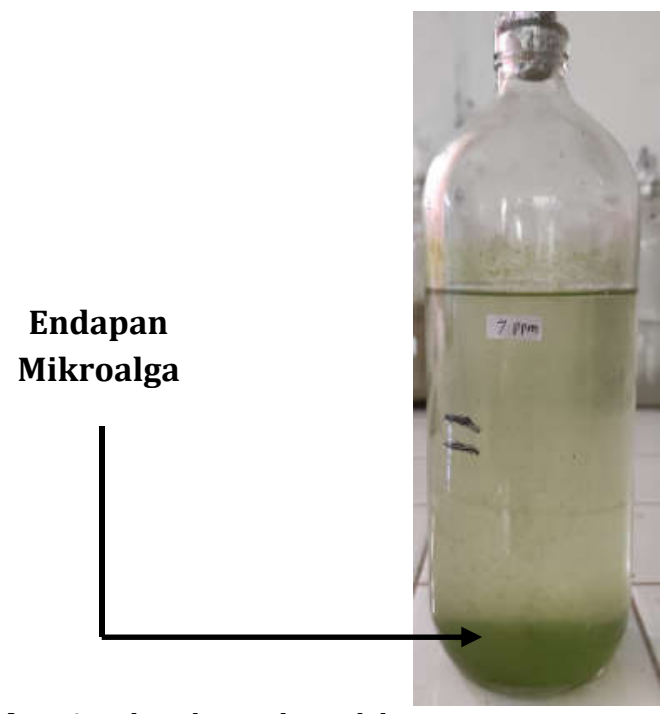

Gambar 6. Mikroalga pada Perlakuan Hg 7 ppm

Mikroalga telah mengembangkan mekanisme ekstraseluler dan intraseluler untuk mengatasi toksiksitas logam berat. Serapan logam berat oleh mikroalga dipastikan lebih unggul dibandingkan dengan proses fisikokimia yang umum digunakan dalam bioremediasi logam berat toksik (Suresh Kumar, Dahms, Won, Lee, \& Shin, 2015; Balzano et al., 2020). Salah satu mekanisme bioremediasi logam berat oleh mikroalga ada dengan mekanisme biosorpsi, yakni kemampuan sel mikroalga untuk mengakumulasi logam berat yang dimediasi secara metabolic ataupun fisiko-kimiawi (Fard, Azimi, \& Bidhendi, 2011; Bilal et al., 2018; Kumar, Singh, \& Sikandar, 2020). Observasi mikroskopik menggunakan mikroskop elektron pada sel mikroalga setelah terpapar logam berat menunjukkan adanya lapisan gelap tebal pada pada permukaan membran sel. Ion logam berat yang dibiosorpsi dan berikatan dengan grup-grup fungsional pada permukaan sel mikroalga dianggap sebagai mekanisme proteksi terhadap paparan sebagian besar ion logam toksik (Shanab, Essa, \& Shalaby, 2012). 
Mekanisme lainnya adalah menggunakan protein pengikat logam yang diekspresikan oleh gen-gen tertentu saat mikroalga berada pada lingkungan yang tercemar logam berat. Protein-protein pengikat logam pada mikroalga di antaraya adalah Metallothionein (MT) dan Phytochelatin (PC). Metallothionein dan Phytochelatin merupakan kelompok protein pengikat logam yang berperan dalam proses bioremediasi logam berat yang dihasilkan langsung dari ekspresi gen maupun secara enzimatik (Balzano et al., 2020; Winarti, Neneng, Gunawan, \& Adam, 2020).

\subsection{Seleksi dan Isolasi Bakteri}

Seleksi dan isolasi bakteri potensial bioremediasi merkuri dilakukan dalam 4 tahap dengan perlakuan konsentrasi Hg yang berbeda. Hasil seleksi tahap 1 menunjukkan bahwa sampel bakteri yang diambil dari areal bekas tambang resisten terhadap perlakuan merkuri (Hg) pada konsentrasi 1 ppm, 3 ppm, dan 5 ppm. Data hasil seleksi tahap 1 secara rinci disajikan pada tabel 1 berikut.

Tabel 1. Hasil Seleksi Bakteri Potensial Bioremediasi

\begin{tabular}{|c|c|c|c|}
\hline \multicolumn{4}{|c|}{ Merkuri Tahap 1} \\
\hline No. & $\begin{array}{l}\text { Perlakuan } \\
\text { Konsentrasi Hg }\end{array}$ & Sumber Sampel & $\begin{array}{l}\text { Persentase } \\
\text { Tumbuh }\end{array}$ \\
\hline \multirow[t]{2}{*}{1} & $1 \mathrm{ppm}$ & $\operatorname{Air}(\mathrm{A})$ & $100 \%$ \\
\hline & & Sedimen (S) & $100 \%$ \\
\hline \multirow[t]{2}{*}{2} & 3 ppm & $\operatorname{Air}(\mathrm{A})$ & $80 \%$ \\
\hline & & Sedimen $(S)$ & $90 \%$ \\
\hline \multirow[t]{2}{*}{3} & 5 ppm & $\operatorname{Air}(\mathrm{A})$ & $60 \%$ \\
\hline & & Sedimen (S) & $10 \%$ \\
\hline
\end{tabular}

Hasil seleksi tahap 1 diberi label masing-masing A1 (Sampel Air, Hg 1 ppm), S1 (Sampel Sedimen, Hg 1 ppm), A3 (Sampel Air, Hg 3 ppm), S3 (Sampel Sedimen, Hg 3 ppm), dan A5 (Sampel Air, Hg 5 ppm). Konsentrasi merkuri dinaikan pada tahap 2 menjadi 3 ppm, 5 ppm, 7 ppm dan 9 ppm. Hasil seleksi tahap 2 menunjukkan sampel bakteri resisten terhadap perlakuan Hg pada konsentrasi 3 ppm, 5 ppm, dan 7 ppm, secara rinci disajikan pada tabel 2 .

Sampel yang tumbuh subur pada tahap 2, kemudian dilanjutkan untuk perlakuan tahap 3 dengan menaikkan konsentrasi Hg menjadi 5 ppm, 7 ppm, 9 ppm, dan $11 \mathrm{ppm}$. Hasil seleksi tahap 3 menunjukkan sampel bakteri resisten terhadap perlakuan $\mathrm{Hg}$ pada konsentrasi 5 ppm, 7 ppm, 9 ppm, dan 11 ppm, secara rinci disajikan pada tabel 3 .

Sampel yang tumbuh subur pada tahap 3, kemudian dilanjutkan untuk perlakuan tahap 4 dengan menaikkan konsentrasi Hg menjadi 11 ppm, 13 ppm, 15 ppm, dan 17 ppm. Hasil seleksi tahap 4 menunjukkan sampel bakteri potensial bioremediasi merkuri yang diambil dari areal tambang emas di Sungai Kahayan, Kalimantan Tengah, resisten terhadap perlakuan Hg sampai konsentrasi 13 ppm, secara rinci disajikan pada tabel 4.

Tabel 2. Hasil Seleksi Bakteri Potensial Bioremediasi Merkuri Tahap 2

\begin{tabular}{lllll}
\hline \hline No. & $\begin{array}{l}\text { Perlakuan } \\
\text { Konsentrasi Hg }\end{array}$ & $\begin{array}{l}\text { Sumber } \\
\text { Sampel }\end{array}$ & Tumbuh & $\begin{array}{l}\text { Persentase } \\
\text { Tumbuh }\end{array}$ \\
\hline 1 & 3 ppm & A1 & A1.3 & $100 \%$
\end{tabular}

\begin{tabular}{|c|c|c|c|c|}
\hline \multirow{3}{*}{2} & \multirow{3}{*}{$5 \mathrm{ppm}$} & $\mathrm{S} 1$ & - & $0 \%$ \\
\hline & & $\mathrm{A} 1$ & A1.5 & \multirow[b]{2}{*}{$100 \%$} \\
\hline & & $\mathrm{A} 3$ & A3.5 & \\
\hline \multirow{5}{*}{3} & \multirow{5}{*}{7 ppm } & $\mathrm{S} 1$ & - & \multirow{2}{*}{$50 \%$} \\
\hline & & S3 & S3.5 & \\
\hline & & A3 & A3.7 & \multirow{2}{*}{$50 \%$} \\
\hline & & A5 & - & \\
\hline & & S3 & S3.7 & $100 \%$ \\
\hline 4 & 9 ppm & A5 & - & $0 \%$ \\
\hline
\end{tabular}

Tabel 3. Hasil Seleksi Bakteri Potensial Bioremediasi Merkuri Tahap 3

\begin{tabular}{|c|c|c|c|c|}
\hline No. & $\begin{array}{l}\text { Perlakuan } \\
\text { Konsentrasi Hg }\end{array}$ & $\begin{array}{l}\text { Sumber } \\
\text { Sampel }\end{array}$ & Tumbuh & $\begin{array}{l}\text { Persentase } \\
\text { Tumbuh }\end{array}$ \\
\hline 1 & $5 \mathrm{ppm}$ & A1.3 & A1.3.5 & $100 \%$ \\
\hline \multirow[t]{5}{*}{2} & \multirow[t]{5}{*}{$7 \mathrm{ppm}$} & A1.3 & A1.3.7 & \multirow{3}{*}{$66,67 \%$} \\
\hline & & A1.5 & A1.5.7 & \\
\hline & & A3.5 & - & \\
\hline & & S1.5 & - & \multirow{2}{*}{$50 \%$} \\
\hline & & S3.5 & S3.5.7 & \\
\hline \multirow[t]{7}{*}{3} & \multirow[t]{7}{*}{$9 \mathrm{ppm}$} & A1.5 & A1.5.9 & \multirow{5}{*}{$50 \%$} \\
\hline & & A3.5 & - & \\
\hline & & A3.7 & - & \\
\hline & & A5.7 & A5.7.9 & \\
\hline & & S1.5 & S1.5.9 & \\
\hline & & S3.5 & S3.5.9 & \multirow[t]{2}{*}{$100 \%$} \\
\hline & & S3.7 & S3.7.9 & \\
\hline \multirow[t]{3}{*}{4} & \multirow[t]{3}{*}{$11 \mathrm{ppm}$} & A3.7 & A3.7.11 & \multirow{3}{*}{$100 \%$} \\
\hline & & A5.7 & A5.7.11 & \\
\hline & & S3.7 & S3.7.11 & \\
\hline
\end{tabular}

Tabel 4. Hasil Seleksi Bakteri Potensial Bioremediasi Merkuri Tahap 4

\begin{tabular}{lllll}
\hline \hline No. & $\begin{array}{l}\text { Perlakuan } \\
\text { Konsentrasi Hg }\end{array}$ & $\begin{array}{l}\text { Sumber } \\
\text { Sampel }\end{array}$ & Tumbuh & $\begin{array}{l}\text { Persentase } \\
\text { Tumbuh }\end{array}$ \\
\hline 1 & 11 ppm & A1.5.7 & A1.5.7.11 & $100 \%$ \\
& & S3.5.7 & S3.5.7.11 & $100 \%$ \\
2 & \multirow{2}{*}{13 ppm } & A1.5.7 & A1.5.7.13 & $100 \%$ \\
& & A1.5.9 & A1.5.9.13 & \\
& & S3.5.7 & S3.5.7.13 & $50 \%$ \\
3 & \multirow{4}{*}{15 ppm } & S3.7.9 & - & \\
& & A1.5.9 & - & \\
& & A3.7.11 & - & $0 \%$ \\
& & A5.7.11 & - & \\
4 & \multirow{4}{*}{17 ppm } & S3.7.9 & - & $0 \%$ \\
& & A3.7.11 & - & 0 \\
& & A5.7.11 & - & 0 \\
\hline
\end{tabular}

Hasil seleksi tahap 4 menghasilkan 3 isolat bakteri potensial bioremediasi merkuri yang resisten terhadap perlakuan Hg tertinggi, yakni 13 ppm. Ketiga isolate tersebut terdiri dari A1.5.7.13 dan A1.5.9.13 dari sampel air, dan S3.5.7.13 dari sampel sedimen (Gambar 7).

Setiap unit perlakuan pada konsentrasi $\mathrm{Hg}$ yang berbeda dalam 4 tahap seleksi mengalami lama fase lag yang bervariasi (Gambar 8). Lamanya fase lag dipengaruhi oleh konsentrasi $\mathrm{Hg}$ pada media tanam bakteri (Irawati et al., 2012). Gambar 8 menunjukkan pada setiap tahap seleksi, sampel bakteri dengan perlakuan $\mathrm{Hg}$ konsentrasi tertinggi membutuhkan waktu untuk tumbuh subur lebih lama dibandingkan pada perlakuan konsentrasi $\mathrm{Hg}$ yang lebih rendah. Sampel bakteri pada konsentrasi Hg yang lebih tinggi mengalami fase lag yang lebih lama karena harus beradaptasi dengan media tumbuh yang mengandung logam berat merkuri. 


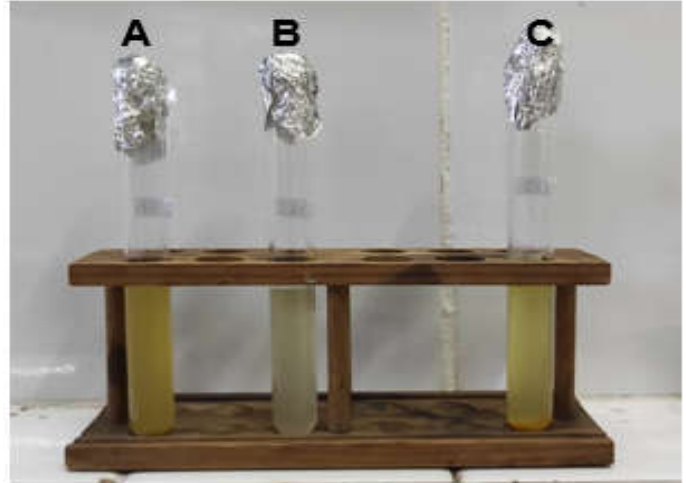

Gambar 7. Isolat: (A) Isolat $1 \mathrm{~A} 1.5 .7 .13$; (B) Isolat 2 A1.5.9.13; dan (C) Isolat 3 S3.5.7.13

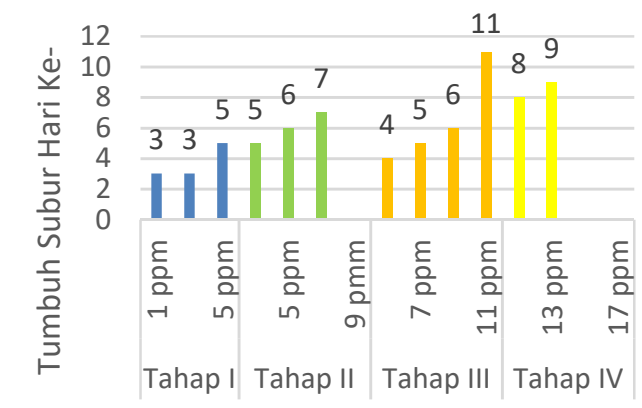

$$
\begin{aligned}
& \text { Seleksi }
\end{aligned}
$$

Gambar 8. Diagram Data Pertumbuhan Setiap Unit Perlakuan pada 4 Tahap Seleksi

Mekanisme resisten bakteri terhadap merkuri didasarkan pada adanya sekelompok gene operon resisten merkuri yang memungkinkan bakteri untuk mereduksi ion logam merkuri yang toksik $\mathrm{Hg}^{2+} \mathrm{ke}$ dalam bentuk merkuri yang volatil $\mathrm{Hg}^{0}$ melalui mekanisme reduksi enzimatis (Summers, 1986; Misra, 1992; Barkay et al., 2003); Operon-operon ini mengandung gen yang menyandikan protein-protein fungsioal untuk regulasi (merR), transport (merT, merP) dan reduksi (merA). Terdapat juga beberapa gen tambahan berupa (merC, merF and merB) (Endo et al., 1995; Nies, 1992). MerB berperan untuk mereduksi merkuri organik. Beberapa bakteri resisten merkuri juga mampu untuk mendetoksifikasi logam berat yang lain, seperti cadmium dan timbal.

\subsection{Identifikasi Morfologi Mikroalga Potensial Bioremediasi Merkuri}

Identifikasi morfologi sampel mikroalga potensial bioremediasi merkuri dari hasil seleksi dan isolasi dilakukan dengan pengamatan morfologis menggunakan mikroskop. Hasil pengamatan morfologis menggunakan mikroskop pada perbesaran kuat $10 \times 100$ menunjukkan bahwa sampel mikroalga potensial memiliki bentuk sel yang sirkuler dan berwarna hijau dengan ukuran sekitar 12 $\mu \mathrm{m}$ (Gambar 9). Karakteristik morfologis tersebut menunjukkan bahwa sampel mikroalga potensial bioremediasi merkuri termasuk ke dalam genus Chlorella.
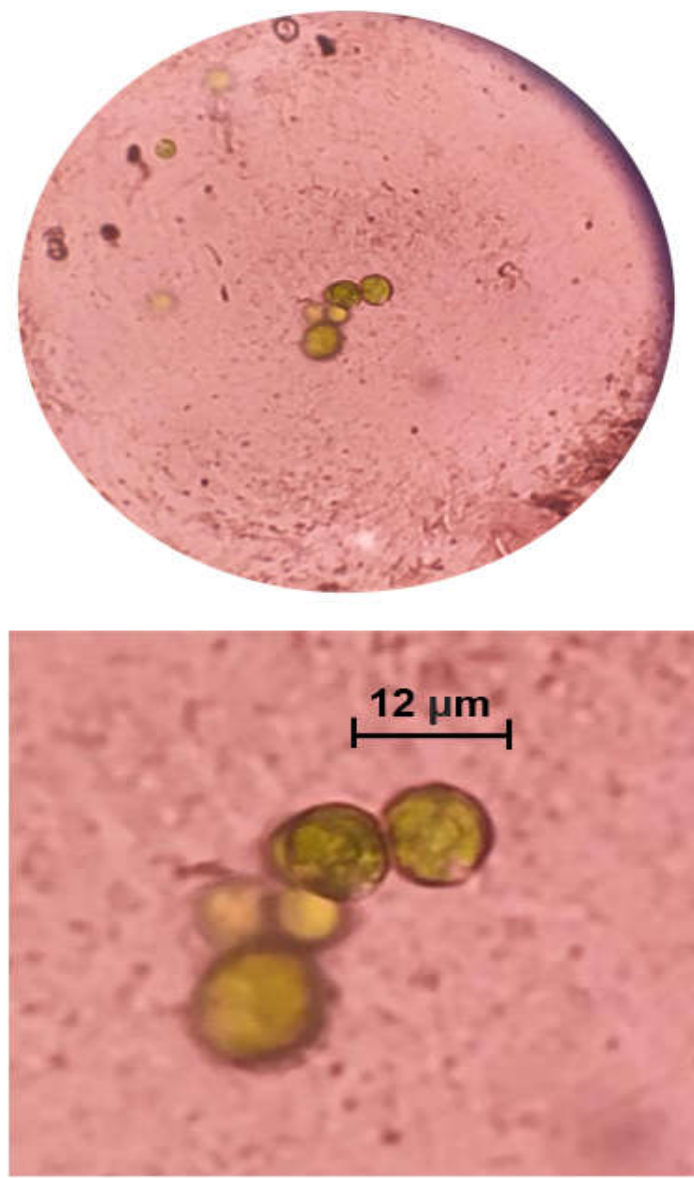

Gambar 9. Hasil Pengamatan Morfologis Sampel Mikroalga Potensial Bioremediasi Merkuri pada Perbesaran $10 \times 100$

Chlorella merupakan organisme uniseluler eukariotik, salah satu genus mikroalga yang termasuk ke dalam kelompok Chlorophyta dengan bentuk sel sirkuler berukuran 2-10 $\mu \mathrm{m}$ (Illman et al., 2000; Krienitz et al., 2004; Yamamoto et al., 2004; Yamamoto et al., 2005). Huss dan Sogin (1990) menyebutkan bahwa ukuran sel Chlorella berkisar antara 2-12 $\mu \mathrm{m}$ dan dapat berubah dengan kondisi kultur yang berbeda.

\subsection{Identifikasi Morfologi Bakteri Potensial Bioremediasi Merkuri}

Identifikasi bakteri potensial bioremediasi merkuri dilakukan dengan metode pewarnaan Gram untuk mengetahui golongan bakteri dan bentuk selnya. Hasil pewarnaan Gram menunjukkan bahwa ketiga isolat bakteri potensial dari hasil seleksi dan isolasi (Gambar 7) termasuk ke dalam golongan bakteri Gram Negatif dengan warna merah muda (Gambar 10). Bentuk sel isolat setelah diamati di bawah mikroskop diketahui berbentuk basil untuk ketiga isolat 1 (I1), Isolat 2 (I2) dan Isolat 3 (I3).

Neneng (2008) menyebutkan bahwa bakteri potensial untuk bioremediasi merkuri dari tambang emas termasuk ke dalam golongan bakteri Gram negatif yang diisolasi dan diidentifikasi dari areal tambang emas di Kalimantan Tengah. 

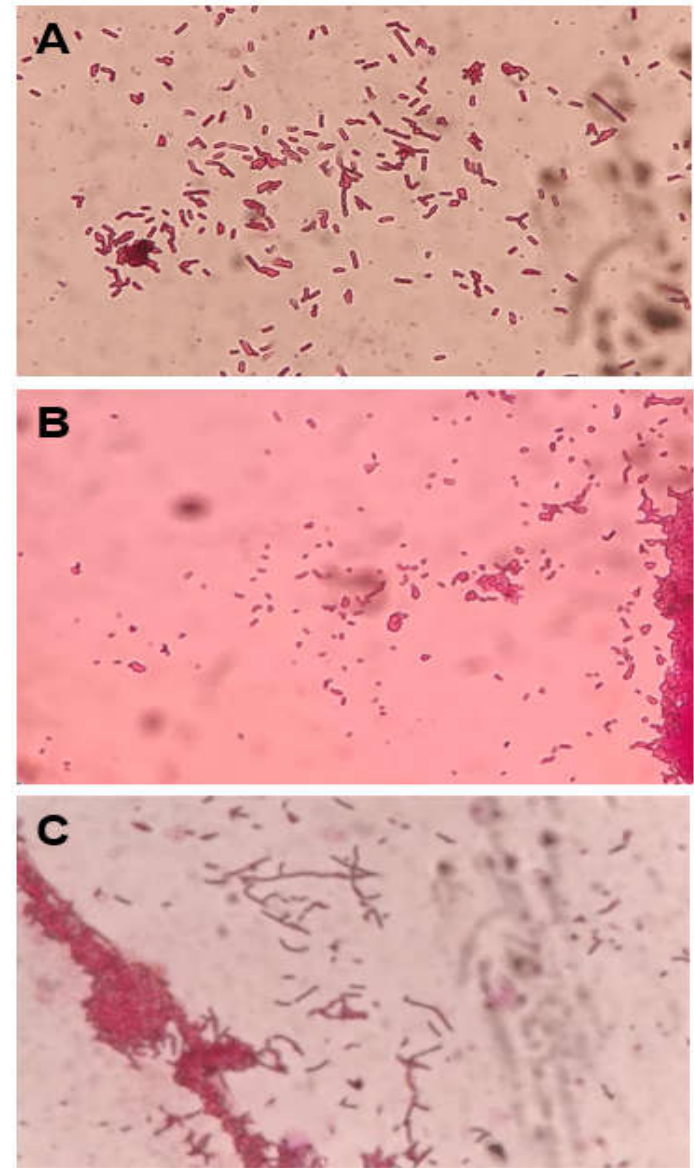

Gambar 10. Hasil Pewarnaan Gram Isolat Bakteri Potensial Bioemediasi Merkuri pada Perbesaran $10 \times 40$ : (A) Isolat 1; (B) Isolat 2; dan (C) Isolat 3

Bentuk koloni isolat bakteri potensial bioremediasi merkuri disajikan pada gambar 11 berikut.

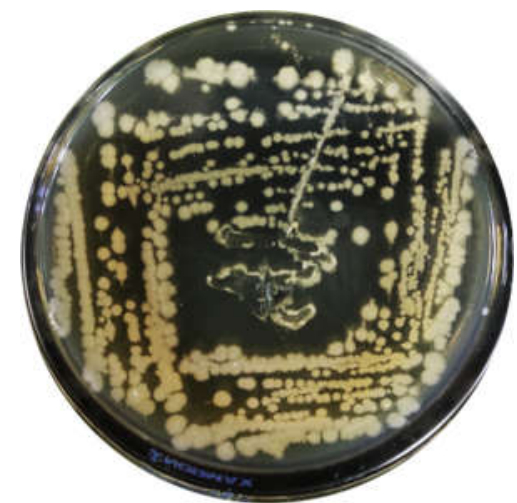

Gambar 11. Bentuk Koloni Isolat Bakteri Potensial Bioremediasi Merkuri pada Media Padat

Isolat 1 (I1) dan isolat 3 (I3) pada media cair menghasilkan pigmen berwarna kuning pekat (Gambar 12). Bakteri potensial bioremediasi merkuri yang menghasilkan pigmen berwarna kuning pekat pada media cair dan termasuk ke dalam golongan bakteri Gram negatif merupakan spesies Pseudomonas sp. (Neneng, 2008; Neneng \& Gunawan, 2018).

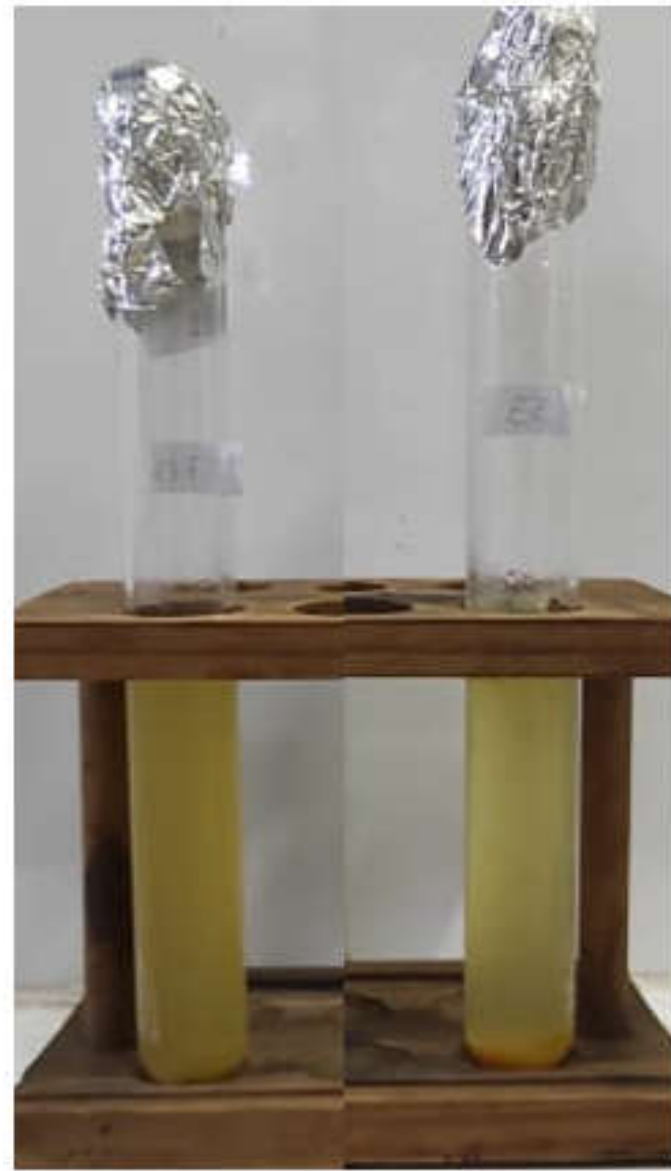

Gambar 12. (A) Isolat 1 dan (B) Isolat 3

\section{Kesimpulan}

Mikroorganisme potensial untuk bioremediasi merkuri dari areal tambang emas Sungai Kahayan Kalimantan Tengah terdiri dari: (1) jenis mikroalga yang termasuk dalam genus Chorella mampu bertahan dengan perlakuan konsentrasi Hg sampai 7 ppm; dan (2) isolat bakteri yang mampu bertahan dengan perlakuan konsentrasi Hg sampai 13 ppm yang terdiri dari 3 isolat, yakni I1 (bakteri dari sampel air), I2 (bakteri dari sampel air), dan I3 (bakteri dari sampel sedimen). Ketiga isolat bakteri potensial termasuk ke dalam kelompok bakteri Gram Negatif. Isolat 1 dan isolat 3 merupakan spesies Pseudomonas sp. berdasarkan kemampuannya menghasilkan pigmen berwarna kuning pada media cair. Penelitian lebih lanjut perlu dilakukan terkait potensi jenis mikoalga lain dari areal tambang emas untuk bioremediasi merkuri.

\section{DAFTAR PUSTAKA}

Al-Rub, F. A. A., El-Naas, M. H., Ashour, I., and Al-Marzouqi, M. 2006. Biosorption of Copper on Chlorella vulgaris from Single, Binary and Ternary metal aqueous solutions. Process Biochemistry, Vol. 41 No. 2. Pages 457-464.

Baldi, F., Bargagli, R., Focardi, S., and Fossi, C. 1983. Mercury and Chlorinated Hydrocarbons in Sediments from the Bay of Naples and Adjacent Marine Areas. Mar. Pollut. Bull. Vol. 14. Pages 108-111.

Balzano, S., Sardo, A., Blasio, M., Chahine, T. B., Dell'Anno, F., Sansone, C., and Brunet, C. 2020. Microalgal 
Metallothioneins and Phytochelatins and Their Potential Use in Bioremediation. Frontiers in Microbiology, Vol. 11. Pages 1-16.

Barkay, T., Kritee, K., Boyd, E., and Geesey, G. 2003. Bacterial Mercury Resistance from Atoms to Ecosystem. FEMS Microbiol, Vol. 27. Pages 355-384.

Bernhard-Reversat, F., and Schwartz, D. 1997. Change in Lignin Content During Litter Decomposition in Tropical Forest Soils (Congo): comparison of exotic plantations and native stands. Comptes Rendus de l'Académie Des Sciences - Series IIA - Earth and Planetary Science, Vol. 325 No. 6. Pages 427-432.

Bertrand, R. L. 2019. Lag Phase Is a Dynamic, Organized, Adaptive, and Evolvable Period That Prepares Bacteria for Cell Division. Journal of Bacteriology, Vol. 201 No. 7.

Bilal, M., Rasheed, T., Sosa-Hernández, J. E., Raza, A., Nabeel, F., \& Iqbal, H. M. N. 2018. Biosorption: An Interplay Between Marine Algae and Potentially Toxic Elements-A review. Marine Drugs, Vol. 16 No. 2. Pages 1-16.

Brune, D., Nordberg, G. F., Vesterberg, O., Gerhardsson, L., and Wester, P. O. 1991. A review of normal concentrations of mercury in human blood. Science of the Total Environment, The, Vol. 100. Pages 235-282.

Chen, J.-Z., Tao, X.-C., Xu, J., Zhang, T., and Liu, Z.-L. 2005. Biosorption of lead, cadmium and mercury by immobilized Microcystis aeruginosa in a column. Process Biochemistry, Vol. 40 No. 12. Pages 36753679.

Chojnacka, K., Chojnacki, A., and Górecka, H. 2005. Biosorption of $\mathrm{Cr}^{3+}, \mathrm{Cd}^{2+}$ and $\mathrm{Cu}^{2+}$ Ions by Blue-Green Algae Spirulina sp.: Kinetics, Equilibrium and the Mechanism of the Process. Chemosphere, Vol. 59 No. 1. Pages 75-84.

Cursino, L., Oberdá, S. M., Cecilio, R. V., Moreira, R. M., Chartone-Souza, E., and Nascimento, A. M. A. 1999. Mercury Concentration in the Sediment at Different Gold Prospecting Sites Along the Carmo Stream, Minas Gerais, Brazil, and Frequency of Resistant Bacteria in the Respective Aquatic Communities. Hydrobiologica, Vol. 394. Pages 5-12.

Dwivedi, S. 2010. Bioremediation of Heavy Metal by Algae: Current and Future Perspective. Journal of Advanced Laboratory Research in Biology, Vol. 3 No. 3.

Endo, G., Ji, G., and Silver, S. 1995. Heavy Metal Resistance Plasmids and Use in Bioremediation. In In: Moo-Young M., Anderson W.A., Chakrabarty A.M. (Eds) Environmental Biotechnology.

Fard, R. F., Azimi, A. A., and Bidhendi, G. R. N. 2011. Batch Kinetics and Isotherms for Biosorption of Cadmium Onto Biosolids. Desalination and Water Treatment, Vol. 28 No. 1-3. Pages 69-74.

Huss, V. A. R., and Sogin, M. L. 1990. Phylogenetic Position of Some Chlorella Species within the Chlorococcales Based Upon Complete Small-Subunit Ribosomal RNA Sequences. Journal of Molecular Evolution, Vol. 31 No. 5. Pages 432-442.

Illman, A., Scragg, A., and Shales, S. 2000. Increase in Chlorella Strains Calorific Values when Grown in Low Nitrogen Medium. Enzyme Microb Technol, Vol. 27.

Imani, S., Rezaei-Zarchi, S., Hashemi, M., Borna, H., Javid, A., Zand, A. M., and Abarghouei, H. B. 2011. Hg, Cd and Pb Heavy Metal Bioremediation by Dunaliella Alga. Journal of Medicinal Plants Research, Vol. 5 No. 13. Pages 2275-2780.

Irawati, W., Patricia, Soraya, Y., and Baskoro, A. H. 2012. A Study on Mercury-Resistant Bacteria Isolated from a
Gold Mine in Pongkor Village, Bogor, Indonesia. HAYATI Journal of Biosciences, Vol. 19 No. 4. Pages 197-200.

Krienitz, L., Hegewald, E. H., Hepperle, D., Huss, V. A. R., Rohr, T., and Wolf, M. 2004. Phylogenetic relationship of Chlorella and Parachlorella gen. nov. (Chlorophyta, Trebouxiophyceae). Phycologia, Vol. 43 No. 5. Pages 529-542.

Kumar, M., Singh, A. K., and Sikandar, M. 2020. Biosorption of $\mathrm{Hg}$ (II) from Aqueous Solution Using Algal Biomass: Kinetics and Isotherm Studies. Heliyon, Vol. 6 No. 1.

Lamaia, C., Kruatrachuea, M., Pokethitiyook, P., Upathamb, E. S., and Soonthornsarathoola, V. 2005. Toxicity and Accumulation of Lead and Cadmium in the Filamentous Green Alga Cladophora fracta (O.F. Muller ex Vahl) Kutzing: A laboratory study. Science Asia, Vol. 31. Pages 121-127.

Leung, M. 2004. Bioremediation: Techniques for Cleaning Up A Mess. BioTeach Journal, Vol. 2. Pages 18-22.

Li, B., Qiu, Y., Shi, H., and Yin, H. 2016. The importance of Lag Time Extension in Determining Bacterial Resistance to Antibiotics. Analyst, Vol. 141 No. 10. Pages 30593067.

Mangindara, A. 2018. Studi Pemanfaatan Fitoplankton (Chlorella sp.) dalam Mengurangi Kadar Logam Berat Merkuri (Hg) di Laut (Universitas Hasanuddin).

Melanson, S. 2017. Toxicity Associated with Mercury. Decision Support in Medicine, LLC.

Mellor, E., Paul, L., Christine O', D., and Dave, C. 1996. The Microbiology of insitu bioremediation. Water Chem, Vol. 66. Pages 257-259.

Misra, T. K. 1992. Bacterial Resistances to Inorganic Mercury Salts Andmorganomercurials. Plasmid, Vol. 25. Pages 4-16.

Nascimento, A. M. A., and Souza, E. C. 2003. Operon Mer: Bacterial Resistance to Mercury and Potential for Bioremediation of Contaminated Environments. Genet Mol Res, Vol. 2. Pages 92-101.

Neneng, L. 2008. Exploration of Potential Isolates Bacterial for Mercury $\left(\mathrm{Hg}^{2+}\right)$ Bioremediation from Gold Mining Area in Kahayan River, Central Kalimantan. Agritek Journal, Vol. 16. Pages 189-194.

Neneng, Liswara, and Gunawan, Y. 2018. The Role of Coenzymes on Mercury $\left(\mathrm{Hg}^{2+}\right)$ Bioremediation by Isolates Pseudomonas aeruginosa KHY2 and Klebsiella Pneumonia KHY3. Journal of Tropical Life Science, Vol. 8 No. 1. Pages 16-20.

Nies, D. H. 1992. CzcR and CzcD, Gene Products Affecting Regulation of Resistance to Cobalt, Zinc, and Cadmium (Czc System) in Alcaligenes Eutrophus. Journal of Bacteriology, Vol. 174 No. 24. Pages 8102 LP - 8110.

Osborn, A. M., Bruce, K. D., Strike, P., and Ritchie, D. A. 1997. Distribution, Diversity and Evolution of the Bacterial Mercury Resistance (Mer) Operon. FEMS Microbiology Reviews, Vol. 19 No. 4. Pages 239-262.

Priyadarshani, I., Sahu, D., and Rath, B. 2012. Microalgal Bioremediation: Current Practices and Perspectives. Journal of Biochemical Technology, Vol. 3 No. 3. Pages 299-304.

Robinson, J. B., and Tuovinen, O. H. 1984. Mechanisms of Microbial Resistance and Detoxification of Mercury and Organomercury Compounds: Physiological, Biochemical, and Genetic Analyses. Microbiological Reviews, Vol. 48 No. 2. Pages 95-124.

Rolfe, M. D., Rice, C. J., Lucchini, S., Pin, C., Thompson, A., Cameron, A. D. S., ... Hinton, J. C. D. 2012. Lag Phase is A Distinct Growth Phase that Prepares Bacteria for Exponential Growth and Involves Transient Metal 
Accumulation. Journal of Bacteriology, Vol. 194 No. 3. Pages 686-701.

Shanab, S., Essa, A., \& Shalaby, E. 2012. Bioremoval Capacity of Three Heavy Metals by Some Microalgae Species (Egyptian Isolates). Plant Signaling and Behavior, Vol. 7 No. 3. Pages 392-399.

Soedarti, T., Tini, S., Sucipto, H., and Eko, P. K. 2017. Bioremediation of Mercury (II) Contaminated Seawater Using The Diatom Skeletonema costatum. KnE Life Sciences.

Summers, A. 0. 1986. Organization, expression and evolution of genes for mercury resistance. Annu Rev Microbiol, Vol. 40. Pages 607-634.

Suresh Kumar, K., Dahms, H.-U., Won, E.-J., Lee, J.-S., and Shin, K.-H. 2015. Microalgae - A promising tool for heavy metal remediation. Ecotoxicology and Environmental Safety, Vol. 113. Pages 329-352.

Von Canstein, H., Li, Y., Timmis, K. N., Deckwer, W. D., \& Wagner-Döbler, I. 1999. Removal of mercury from chloralkali electrolysis wastewater by a mercuryresistant Pseudomonas putida strain. Applied and Environmental Microbiology, Vol. 65 No. 12. Pages 5279-5284.
Wagner-Döbler, I., Canstein, H. V., Li, Y., Timmis, K. N., \& Deckwer, W. D. 2000. Removal of Mercury from Chemical Wastewater by Microorganisms in Technical Scale. J. Environ. Sci. Technol., Vol. 34 No. 21. Pages 4628-4634.

Walsh, B. 2013. Urban Wastelands: The World's 10 Most Polluted Places.

Winarti, S., Neneng, L., Gunawan, Y. E., and Adam, C. 2020. Analysis of Genetic Profiles of Heavy Metal Phytememediator Plants From Gold Mining Areas. Vol. 4 No. 1. Pages 11-20.

Yamamoto, M., Fujishita, M., Hirata, A., and Kawano, S. 2004. Regeneration and Maturation of Daughter Cell Walls in the Autospore-Forming Green Alga Chlorella vulgaris (Chlorophyta, Trebouxiophyceae). J Plant Res, Vol. 117.

Yamamoto, M., Kurihara, I., and Kawano, S. 2005. Late Type of Daughter Cell Wall Synthesis in One of the Chlorellaceae, Parachlorella kessleri (Chlorophyta, Trebouxiophyceae). Planta, Vol. 211.

Yulianti, F., Alumni, Yustiani, M., \& Afiatun. 2007. Identifikasi Kandungan Merkuri (Hg) dalam Air dan Sedimen Sungai Kapuas Tengah di Daerah Pertambangan Emas Tanpa Ijin (PETI). Universitas Pasundan. 